\title{
TOURISM IMPACTS IN BHEDETAR, DHANKUTA DISTRICT, NEPAL
}

\author{
Dhyanendra B. Rai*
}

\begin{abstract}
This paper is an attempt to explore the tourism impacts in Bhedetar, Dhankuta, one of the unique and popular places of eastern Nepal for its pleasant weather and aesthetic natural landscape to tourists particularly from Nepal and India. Based on the data collected from the field survey, including the methods such as household questionnaire, key informants survey and participatory observation, this paper discusses the impacts of tourism based activities and enterprises in both positive and negative terms on nature, society, culture and economy of Bhedetar. At the end, it suggests the roles of local organizations, district government and national government in delivering services and infrastructure for the promotion of tourism in Bhedetar.
\end{abstract}

\section{INTRODUCTION}

Tourism is one of the most diverse, dynamic and fastest growing industries particularly in the developing World (Bhatia, 2000; Pathak, 2012). It is a major source of foreign currency for developing countries and therefore, it is considered as an important sector of investment.

Tourism activities often bring about changes in environment, economy and socio-cultural condition of the destination places or area. These changes are considered as tourism impacts. The tourism will have positive impacts if the changes take place in desired direction, but otherwise it will have negative impact due to undesirable changes (Pagdin, 1995). Nature and culture are two important resources for tourism and therefore they are to be conserved. Employment opportunity, income generation activities, occupational diversity, social mobility, protection and upgrading of public places and infrastructures development are the main positive aspects of tourism. On the other hand, deterioration of natural environments like deforestation, water pollution, soil erosion, haphazard waste disposals, etc are some of the adverse effects of tourism (Joshi, 2008). Jinha (1995) suggests that a well planned tourism brings positive benefits while an uncontrolled and unmanaged tourism may cause negative impacts on natural and cultural resources. Further, impacts are less visible when the tourism is limited whereas with the increase in the tourism activities they are more visible. Principally ecotourism does not have negative impacts in the destination but in practice there is nothing like zero impacts. Even the most benign forms of ecotourism will still have some negative impacts on environment (Bhatt, 2006). Furthermore, there needs to devise alternative tourism approaches that minimize the negative impacts of tourism as well as integrate economic development of the

Mr. Rai is an Associate Professor, Central Department of Geography, T.U., Kathmandu, Nepal. 
people through making local communities aware about conservation of the natural and cultural environments (Sharma, 1998). This paper examines the impact of tourism on the local environment, socio-cultural and economic sector of Bhedetar.

\section{METHODS AND MATERIALS}

The data for this paper were collected from the field survey carried out in Bhedetar by using questionnaires to the hotel and lodge enterprises and tourists. Information was gathered from the key informants such as local social worker, hotel proprietors, contractor of Charles Tower, and secretary of the Village Development Committee (VDC) by using checklist and likewise eight participants including local intellectuals, businesspersons, and farmers through FGD were asked information regarding impacts. Census survey was done in the case of great hoteliers being existed there in the number of nine. For the small hoteliers (Catering type), it was taken ten percent sample of forty catering. In the context of tourist informants, it was selected randomly available in the spot in which one was international and other five were internal tourist. Detailed observation was also carried out to see the environmental impacts.

\section{THE STUDY AREA}

Bhedetar is a hill station located at the altitude of 1,420 masl, which is $14 \mathrm{~km}$ north from nearest city, Dharan in the Tarai and $37 \mathrm{~km}$ south from Dhankuta, the headquarters town of eastern region. It is situated at the junction crossed by Dharan-Dhankuta highway and the Rajarani road. The centre extends over two VDCs such as Bhedetar of Dhankuta district and Panchakanya of Sunsari district. There are 45 households and 225 people.

Figure 1: Location of Bhedetar, eastern Nepal

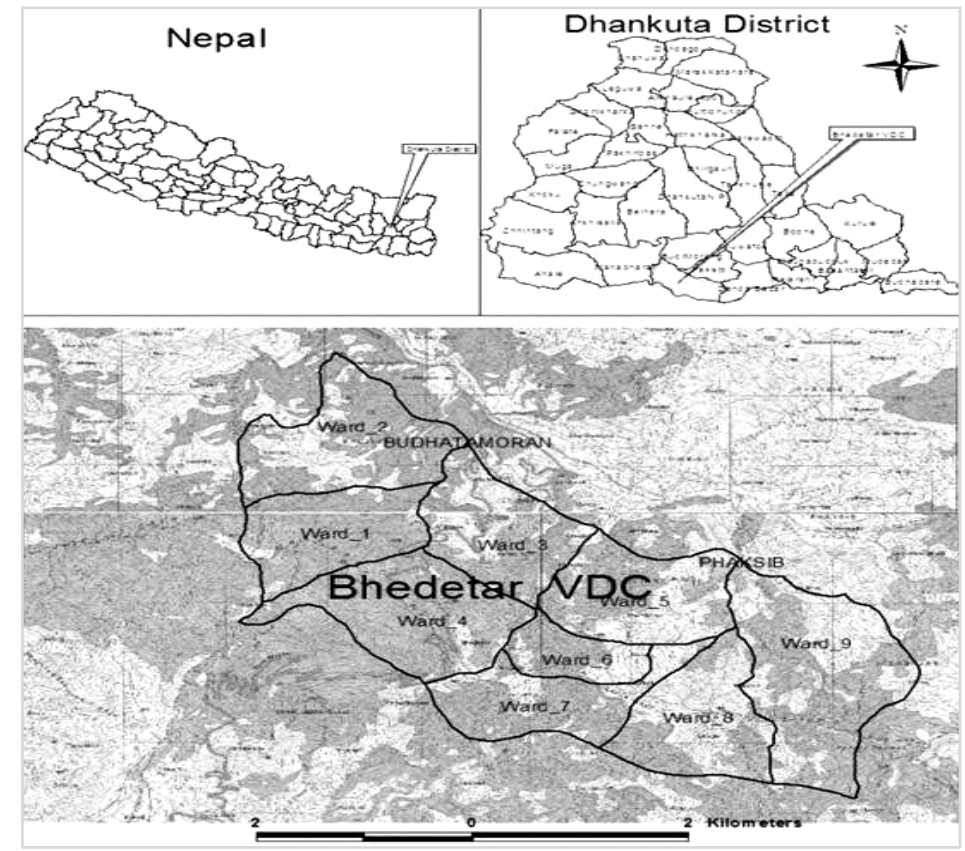




\section{TOURISM IN BHEDETAR}

\section{Development history}

Bhedetar has a very short history about its origin. It was unknown and desolated place until 1977. There was not a single house and the area was used for grazing flocks of sheep during the winter season as transhumance by the Gurungs from places of surrounding districts such as Taplejung, Terhathum and Sankhuwasabha. Perhaps the name of this place etymologically became 'Bhedetar' (Bheda = sheep and tar = terrace land for grazing) due to this context. About 50-60 years ago, Dharan began to develop as the market centre for the people of surrounding hill districts like Dhankuta, Bhojpur, Terhathum, Khotang, and Sankhuwasabha,. During that time the British camp was also established in Dharan and gradually the town was covered by the Lahures (working or retired military men). Later the Lahure families developed a kind of culture, known as 'Lahure Culture', which meant the people especially from the Lahure's family used to visit Bhedetar for spending time for pleasure and relax out of the pierce hot summer. As there were no houses and facilities for eating, drinking and rest, they had to back home after spending some time. Bhedetar gradually got eating facilities and rest place for the public bus travelers after opening of DharanDhankuta highway in 1982 and then other activities for tourism. The importance of Bhedetar for tourism got increased after visiting this place by British Prince Charles and the built up of Charles Tower in the 80s. These provided impetus to Bhedetar to attract more tourists from within and outside the country. Now it is the station for all sorts of people and especially for the youths to spend time for eating, drinking, pleasure and sightseeing particularly during the summer days.

\section{Origin of tourists}

The origin of tourists at Bhedetar is mainly of domestic one, accounting for 91 percent that comprises eastern region and other regions within Nepal. The Indian tourists share 8 percent of the total tourists of 13,500 . The origin places of the domestic tourists from the eastern region include Dharan, Itahari, Inaruwa, Biratnagar, Dhankuta, and other places and the people from these places as well as from nearby cities of India like Jogbani, Siliguri, Darjeeling, Farbesganj, etc are found visiting Bhedetar in order to escape terrible hot. The tourists from Europe and USA have no special season to visit Bhedetar.

Figure 2: Origin of Tourists by Place

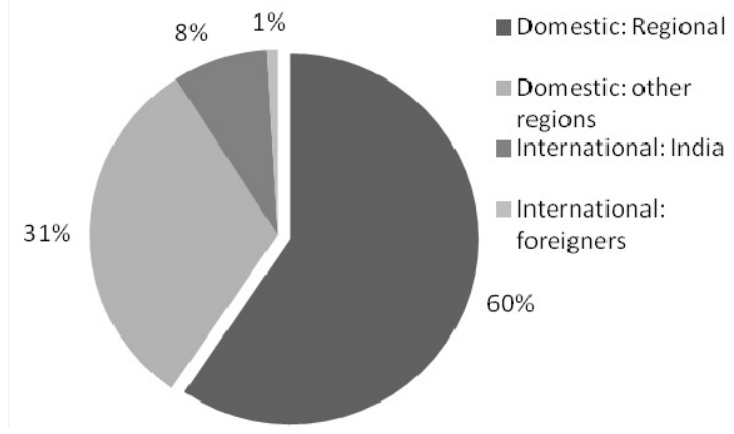

Source: Field Survey, 2010. 


\section{Purpose of visit}

Bhedetar is found to be visited primarily for recreation and holiday pleasure due to pleasant weather; these two combine together represent about 80 percent of the total tourists (Table 1). Under sightseeing activity, magnificent views of the Himalayan peaks and greenery hills to the north and the Tarai lowland fields to the south can been seen from this place during clear weather. The businesspersons, government staff, and professionals often with their families used to visit Bhedetar for holiday. Groups of people representing different organizations and education institutes from different parts of the country such as Kathmandu, Pokhara, Hetauda, Birganj, Nepalganj, Dhangadhi, and Mahendranagar used to visit Bhedetar under the package tour program of the eastern Nepal. There are hotels with facilities for organising meeting, seminar, training programs, etc and therefore different agencies including NGOs, INGOs, government and political parties are used to organize programs in Bhedetar.

Table 1: Purposes of Visit

\begin{tabular}{|l|c|c|}
\hline \multicolumn{1}{|c|}{ Purpose } & No. of tourists & Percent \\
\hline Recreation & 7500 & 55.5 \\
\hline Holiday & 3200 & 23.7 \\
\hline Tour & 1200 & 9.0 \\
\hline Seminar/meeting & 1000 & 7.4 \\
\hline Others Total: & 600 & 4.4 \\
\hline \multicolumn{2}{|c|}{ 13500 } & $\mathbf{1 0 0 . 0 0}$ \\
\hline
\end{tabular}

Source: Field Survey, 2010.

Figure 3: Duration of Stay

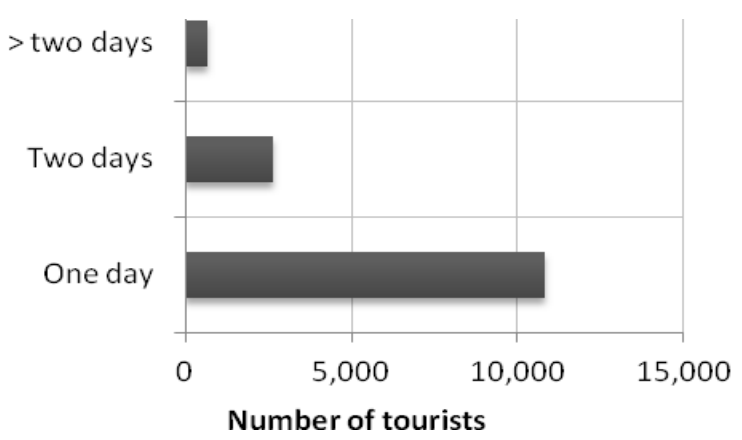

Bhedetar is found to be visited by tourists under organized or group tourism; about 77 percent of the total tourists $(13,500)$ come under this category, whereas individual tourists share 23 percent. 


\section{Length of stay and expenditure}

The duration of stay depends on the various activities and facilities offer by the touristic place. About 80 percent of the total tourists found to have spent only one day and 15 percent for two days (Fig. 3). It is obvious that Bhedetar being developed on the terrace slope has limited physical space. Now, Bhedetar has challenge for its stakeholders (local government and enterprises) about how to lengthen the staying of tourists.

Amount of expenditure by tourist is determined by the activities and facilities and the length of stay. As the length of stay of tourists being very short, their total amount of expenditure earned by the enterprises would be also limited. Being a cool place, demand for drinks is very high in Bhedetar and recreation, pleasure and holiday activities made by majority of the tourists. The survey shows about 55 percent of the total amount found to be spent on foods and drinks and 15 percent went for accommodation and transportation ${ }^{1}$. Tourists found to have spent 5 and 10 percent for the souvenir and others. These findings can be compared with the study in Ladakh, India by Jinha (1995), where the tourists visited for holiday and recreation spent more money for foods and drinks.

\section{Tourism peculiarities of Bhedetar}

The resources locally available and offered by Bhedetar are important and peculiar for tourism development. The resources may be in tangible or intangible form. Bhedetar possesses the resources as peculiarities for tourism development are unique cool weather, panoramic view of the hills and mountains, Charles Tower, and the Spirit of Place (Memorial to the Magar Ancestors).

One of the beauties and attractions of Bhedetar is its cool, fresh weather with warm sun shine that provides pleasing weather to the tourists. This is usually a key element of tourism (Upadhya 2008). At the altitude of 1,420 masl and within annual average temperature ranging $10^{\circ} \mathrm{C}$ to $20^{\circ} \mathrm{C}$, most of the weather of Bhedetar appears to be mild, warm and pleasant, primarily to the people of the places such as Tarai and warm hill regions of Nepal where temperature during the summer is very hot. Changeable nature of weather during the day is uniqueness of Bhedetar, with often sunny in the morning, foggy in the late morning and sometimes raining in the mid-day during summer season.

1 During the survey, there were six hotels with beds and modern facilities, parking, meeting halls, picnic spot and panoramic view and sightseeing. 
Figure 4: Location of Bhedetar, Eastern Nepal

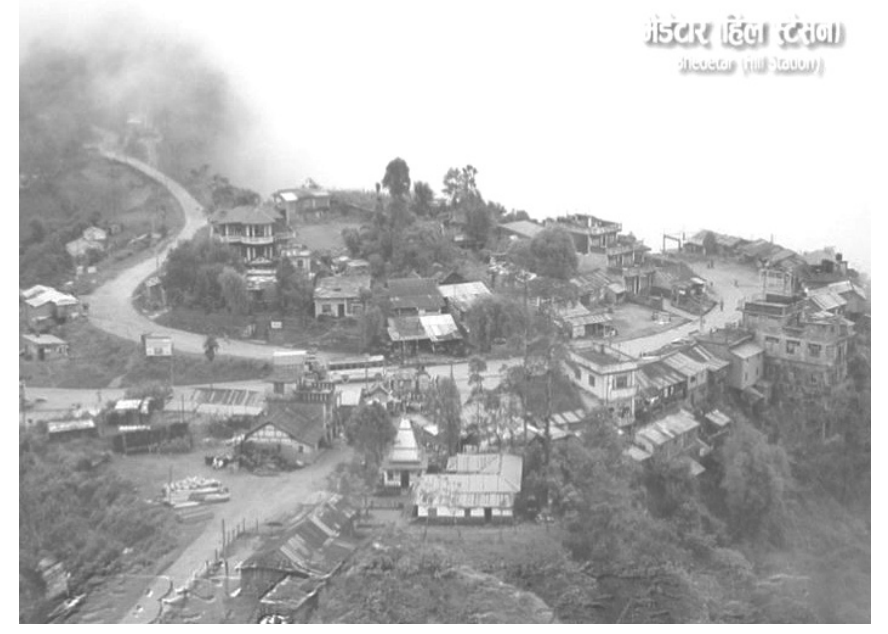

Secondly, the geographical location of Bhedetar on the top of the hill offers panoramic view of the Tarai plain fields, Charkoshe Jhadi, the Saptakoshi River, and Dharan bazaar far down to the south and the Himalaya ranges and peaks such as Makalu, Gaurishankar, Singhlila and Kumbhakarna to the north during autumn season.

Figure 5: Memorial to the Magar Ancestors, Namje

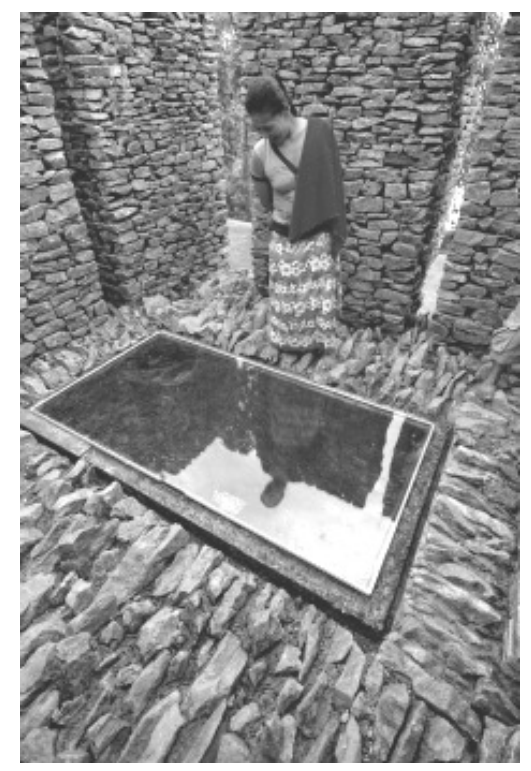

The third attractive element of tourism is the beautiful tower situated at the top of the Sailungdanda. The tower has been named after Prince Charles who visited Bhedetar for the first time in 1980s and built by the district government of 
Dhankuta in 2000. The visitors can enjoy viewing the surrounding unspoiled landscapes, green forest, the Bhedetar itself from the tower.

The last but not the least is the 'Memorial to the Magar Ancestors', with 7foot-high stacked-stone walls surround a 3x6-foot opening in the earth, edged with standing stones, symbolizing the sea of souls and covered by laminated glass. The glass connects the reflected sky above with the earth visible beneath it. The memorial was constructed by Catholic University students of USA in Namje village, Bhedetar in June 2011 (website). ${ }^{2}$ The goal is to explore the design and construction of architectural forms that are able to successfully respond to their natural and cultural settings, as well as to create a village tourism plan with home stay packages. In addition, the site includes agricultural fields for permaculture and organic farming and growing 50 different species of plants by the villagers of Namje and Thumki.

\section{Tourism impacts analysis}

Tourism impacts in Bhedetar have been analysed based on the information obtained from FGD as depicted in Table 2.

Table 2: Assessment o Tourism Impact

\begin{tabular}{|c|c|c|}
\hline \multirow{2}{*}{ Attributes } & \multicolumn{2}{|l|}{ Types of impacts } \\
\hline & Positive & Negative \\
\hline $\begin{array}{l}\text { Physical } \\
\text { impacts }\end{array}$ & $\begin{array}{l}\text { - Environmental consciousness among } \\
\text { people } \\
\text { - Realized of importance of natural beauty } \\
\text { and flora and fauna } \\
\text { - Realized importance of forest by local } \\
\text { people } \\
\text { - Awareness about hygiene and sanitation }\end{array}$ & $\begin{array}{l}\text { - Deforestation for } \\
\text { firewood } \\
\text { - Encroachment of } \\
\text { public land } \\
\text { - Soil erosion }\end{array}$ \\
\hline $\begin{array}{l}\text { Socio- } \\
\text { cultural } \\
\text { impacts }\end{array}$ & $\begin{array}{l}\text { - Cultural exchange between local people } \\
\text { and tourists } \\
\text { - Realized of preservation of local culture } \\
\text { and tradition } \\
\text { - Growth of cultural pride and value } \\
\text { - Exposure of the people }\end{array}$ & $\begin{array}{l}\text { - Cultural imitation } \\
\text { - Socio-cultural } \\
\text { conflicts } \\
\text { - Eroding local } \\
\text { cultural values and } \\
\text { traditions }\end{array}$ \\
\hline $\begin{array}{l}\text { Economic } \\
\text { impacts }\end{array}$ & $\begin{array}{l}\text { - Diversification in income source } \\
\text { - Improvement in the level of life standard } \\
\text { - Infrastructure development } \\
\text { - Improvement in land use pattern } \\
\text { - Increase in land value }\end{array}$ & $\begin{array}{l}\text { - Winter } \\
\text { unemployment } \\
\text { - Lack of labour in } \\
\text { agricultural sector } \\
\text { - Over dependency } \\
\text { on imported goods } \\
\text { - Growing } \\
\text { expensiveness }\end{array}$ \\
\hline
\end{tabular}

Source: Field Survey, 2010.

2 The 'Spirit of Place Architecture Program' has received Top Honors and has now been featured as CNN's 12 best unheard of places 
Under physical impacts, one crucial issue is the preservation of the environment as a prerequisite for sustainable development of tourism. Local people are aware about hygiene and sanitation. For instance on each Saturday, they sweep the streets of the bazaar area; have created a community forestry user's group to manage the local forest. Despite these, the act of encroachment over the sloppy and vulnerable land by the buildings and expansion of buildings, malpractice of cultivation on steep slopes, road construction, etc have caused to soil erosion and landslides, particularly the soil erosion in Sailungdanda appears to be problematic.

On socio-cultural perspective, local people have spirit of preservation of local culture and tradition, but the cultural imitations among the young generation which reflected through dress, language, food and festivals, etc. have begun to appear, threatening to the erosion of local cultures and traditions. The criminal activities which were virtually non-existent appear to occur sometimes.

Economically, the tourism in Bhedetar has helped to increase income generation of the local communities through the sales of local handicrafts and arts, providing market for local products such as vegetables, fruits, milk, butter, meat, etc. It is estimated that almost Rs 20 million are transacted annually due to tourism in Bhedetar. The surrounding areas like Jamune, Rajarani, and others have got benefits by selling vegetables and livestock and poultry products and by getting employment in the hotels and restaurants. There has been diversification in income source of local people. Despite all these benefits, conflicts between enterprises and stakeholders appear to have existed for using benefits and utilizing local resources.

\section{Role of organizations}

The local governments, particularly the district development committee, central government, NGOs and private sector are crucial in providing infrastructures like road, transport and communication, electricity, drinking water view-tower, etc. for tourism development in Bhedetar. The drinking water project was built by the Gorkha Welfare Service (GWS) and likewise the Bhedetar Hotel Association has been established by the Nepal Academy of Tourism and Hotel Management (NATHM). Activities and training about sanitation and hotel management among the local people have been held.

The tourism impacts in Bhedetar can be compared and verified with similar studies carried out in several areas of Nepal. Tourism impacts indeed vary from place to place and society to society in terms of social, cultural ecological and economic and environmental conditions of the tourism places (Pagdin, 1995; Jinha, 1995; Joshi, 2008; Bista, 1994). Socio-cultural benefits from the tourism are dependent on the receptive capacity of the local communities (Pandey et al., 1995). Tourism has caused natural environment imbalance between life forms and other substances (Bhatt, 2006). Local communities have got benefits from selling locally produced goods such as vegetable, fruits, milk, butter, meat etc and thus creating additional employment opportunities to the local people (Sapkota and Dahal, 1998). On top of them, the government plans are important in 
strengthening the tourism in the country. For instance, the government planning for tourism has focused on creating employment and social inclusion and more regional balance throughout the country (NPC, 2007).

\section{CONCLUSION}

Tourism is an important industry from the perspectives of earning foreign currency, local employment generation and use of local production resources and to these contexts, Bhedetar is one of the places for tourism development in eastern Nepal. Tourism has a very short history and developed recently in Bhedetar only after the building of highway in the early 1980's that passes through this place linking south and north and particularly due to rapid urban growth of Dharan town and Bhedetar being situated at the top of the hill acts as a unique place, offering cool and pleasant weather conditions and scenic view for recreation and holiday to the people living in the south where there is hot climate during summer and spring seasons. Tourism has provided benefits to the people working in this sector, but Bhedetar has to expand its activities to attract many more people from within the country as well as from abroad particularly India to lengthen their stay in Bhedetar, then only many more people get benefits from tourism. For instance, if infrastructures are built such as cable car from Bijayapur, Dharan to Bhedetar and airport in Dharan may help to increase tourists in Bhedetar. Health and education facilities are other potentials for enhancing tourism in Bhedetar. Further, community based tourisms such as village or home stay tourism in the Magar villages in the surrounding areas of Bhedetar which have already got successful in many other parts of the country require to be developed for enhancing tourism.

After expanding tourism activities in Bhedetar, it has increased environmental consciousness in local people. Cultural pride and value has also increased among the local people. Due to the multiplier effects of tourism upon the different sectors of local area have created positive change in the socioeconomic condition of the people. Availability of employment opportunity, income generation and diversification of income source etc. are some of the important advantage of tourism in this area.

\section{WORKS CITED}

Bhatia, A.K. (2000). Tourism Development: Principles and Practices. Sterling Publishers, New Delhi.

Bhatt, D.P. (2006). Ecotourism in Nepal: Theoretical Concepts and Principles. Anju Bhatt, Kathmandu.

Bista, H. (1994). Tourism in Garhwal Himalaya: With Special Reference to Mountaineering and Trekking in Uttarkashi and Chamoli Districts. Indus Publishing Company, New Delhi.

Jinha, P.S. (1995). Impact of Tourism on Ladakhi Society and Culture. In: Wariko, K. (Ed.), Society and Culture in the Himalayas. Har-ananda Publications. 
Joshi, D.R. (2008). Socio-Economic Impact of Tourism in Nepal: Orden or Paradox. In Upadhya, R. (Ed.). Readings in Rural Tourism. Sunlight Publication, Kirtipur, Kathmandu.

Modi, S. (2001). Tourism and Society. Rawat Publication, Jaipur and New Delhi.

NPC (2007). Three Year Interim Plan (2007-08/2009/10), National Planning Commission.

Pagdin, C. (1995). Assessing tourism impacts in the Third World: a Nepal case study. Progress in Planning. Vol. 44: 185-266.

Pandey, R.N. Chhetry, P., Kunwar, R.R. and Ghimire, G. (1995). Effects of Tourism on Culture and the Environment- Case Study of ChitwanSauraha and Pokhara-Ghandruk. A Report Submitted to UNESCO, Principal Regional Office for Asia and the Pacific, Bangkok, Thailand.

Pathak, R.S. (2012). Tourism Geography: with Special Reference to Nepal. Uma Pathak, Kathmandu.

Rao, N. (2008). Trends in tourism: spectres of new displacements. In: Mishra R. et al. (Eds.), Tourism Development Revisited: Concepts, Issues and Paradigm. Sage, New Delhi.

Sapkota, K. and Dahal, K. (1998). Trekking tourism in Langtang region. The Himalayan Review. Vol. 29: 64-76.

Sharma, P. (1998). Approaches to promoting mountain tourism for local development: experiences from Nepal. The Himalayan Review. Vol. 29: 20-36.

Upadhayay, R. (2008). A case study of rural tourism in Sirubari, Bandipur and Ghalegaun. In: Upadhyay, R (Ed.). Readings in Rural Tourism. Sunlight Publication, Kathmandu.

Upreti, H.K. (1998). Eco-tourism with people's participation for sustainable development. The Himalayan Review. Vol. 29: 53-63.

www.architizer.com/en_us/people/login/?location_url=/en_us/projects/view/?cou ntry=en_us 